\section{Mangelen på helse- arbeidere i Afrika verre enn antatt}

En ny studie tyder på at mangelen på helsepersonell i Afrika er enda mer kritisk enn tidligere antatt. I ti av 12 land som var inkludert i studien, utdannes for få helsepersonell til å vedlikeholde nåværende tetthet (1).

Informasjon om antall helsearbeidere og personer som fullførte utdanningsprogrammer samt mortalitetsdata ble hentet fra Verdens helseorganisasjon, mens befolkningsestimater kom fra FN.

Mangelen på helsepersonell i Afrika skyldes mange faktorer, som for lite investering i utdanning, internasjonal utvandring, karriereendringer blant helsepersonell, tidlig pensjonering og tidlig død.

Verdens helseorganisasjon har satt et mål om 2,28 helsearbeidere per 1000 innbyggere, men med nåværende tap av helsearbeidere og for lavt omfang av utdanning vil få av landene inkludert i studien kunne oppnå dette. Om tap av helsepersonell ble begrenset til ufrivillige årsaksforhold som tidlig død, ville det for landene totalt ta 36 år å nå Verdens helseorganisasjons mål for leger og 29 år for sykepleiere og jordmødre. Og noen av landene ville aldri nå dette målet.

I minst seks av de 12 landene utdannes for få til å opprettholde nåværende antall helsearbeidere, som også i dag er for lavt til å møte befolkningens helsebehov.

- Utdanningskapasiteten må økes og kombineres med andre intervensjoner for å øke tilførselen og redusere tapet av helsearbeidere, sier førsteforfatter Yohannes Kinfu.

\section{Oda Riska}

oriska@hotmail.com

Tidsskriftet

\section{Litteratur}

1. Kinfu Y, Dal Poz MR, Mercer $\mathrm{H}$ et al. The health worker shortage in Africa: are enough physicians and nurses being trained? Bull World Health Organ 2009; 87: 225-30. doi: 10.2471/BLT.08.051599.

\title{
Et kall fra helvete
}

\author{
Blant de endelig avviste asylsøkere i Norge finnes det leger som \\ har nektet å bidra til tortur i hjemlandet. De blir ikke trodd. Utlendings- \\ direktoratet synes at slikt er så usannsynlig at asylsøknadene blir \\ avslått.
}

«Johan»s historie er et typisk eksempel. Han tør ikke vende hjem pga. reell fare for fengsling, lemlestelse eller drap. Han lever en skyggetilværelse, overnatter hos venner og kjente og tjener litt på strøjobber som vaskehjelp. Han kan ikke åpne en bankkonto og har ikke rett til helsehjelp. Nye briller, en tannlegeregning eller nødvendige medisiner blir uoverkommelige utgifter.

\section{Min venn}

Johan ble ved en tilfeldighet min venn. Hans kone og barn risikerer represalier i hjemlandet om han står frem med sin historie. Han kommer fra et mektig diktatur hvor prester har all makt i regjering og parlament. I bunn og grunn er han ikke politisk interessert. Han betrakter legegjerningen som et kall.

Han er utdannet i et EU-land. Siden dro han hjem for å avtjene turnustjenesten som han hadde forpliktet seg til. Problemene lot ikke vente på seg. Medisiner og utstyr som var bevilget til helsesenteret ble for en stor del forbeholdt sjefens venner eller solgt videre til inntekt for sjefen. Johan sa fra, og han ble utsatt for trusler.

Med sitt EU-diplom begynte han derfor å se seg om etter jobbmulighet i Europa. Fra Norge fikk han ikke bare svar, han fikk full legeautorisasjon. Johan valgte å bli i hjemlandet. Tingene hadde roet seg, han hadde kommet til et nytt sted med et nytt helsesenter og han hadde giftet seg.

Men han klarte ikke å holde munn da et medisinsk inngrep ble krevd avbrutt når det var tid for bønn. Han protesterte når vanskelig tilgjengelige, livreddende medikamenter ble pålagt brukt til behandling av en bagatell hos en av klinikksjefens venner. Han reagerte på at sjefene oftest hadde nådd sin posisjon gjennom korrupsjon og fordi de var rettroende. Derfor ble han innkalt til etterretningstjenesten. Her ble han innesperret $\mathrm{i}$ ti dager uten adgang til toalett eller bøtte. Han ble forhørt, slått og sparket. Han ble ikke sluppet ut før han skrev under på at han ville innrapportere enhver som ytret seg negativt om regimet.

Han åpnet egen praksis og tjenestegjorde i tillegg ved den lokale legevakten.

En kveld brakte to gardister inn en mann som åpenbart var torturert. De krevde at Johan sjekket mannens helsetilstand og påla ham å stille en «ufarlig» diagnose, men de nektet ham å gi behandling. Få dager senere var mannen død. Hendelsen var skjellsettende.

Johan fikk tillatelse til å søke visum til et etterutdanningsopphold på noen uker i EU-landet der han hadde studert medisin. Kvelden før avreisen tok han en ekstravakt. Det har han angret på mange ganger, fordi det førte til at han ikke har sett kone og barn på fem år. Han angrer ikke at han fulgte sin samvittighet: «Jeg kunne ikke annet, jeg er jo lege.»

Denne natten kom gardistene med en kvinnelig medisinstudent. Hun var voldtatt og mishandlet av vokterne - hun fryktet for sitt liv. Med hans hjelp klarte hun å flykte fra sykehuset. Da han innså hva han hadde gjort, rømte han i angst og hørte skudd bak seg. Da flyet lettet, pustet han lettet ut.

Etter ankomst ringte han hjem og traff sin kone i gråt og fortvilelse. Han kan ikke vende tilbake til hjemlandet. Politiet hadde vært hjemme hos ham og endevendt huset. Han skulle avhøres og fengsles for sine misgjerninger. Etter hvert sluttet man å trakassere kona mot at faren ga fra seg skjøtet på huset sitt. Hvis Johan ikke straks meldte seg etter hjemkomst, ville han miste huset.

\section{Norge}

I panikk hørte han på besserwissere som anbefalte ham å dra til Norge, Fridtjof Nansens land. Han hadde jo autorisasjon som lege der. Menneskesmuglere førte ham hit og tok fra ham passet.

Nå er hans flyktningstatus avvist. Han ble ikke trodd av verken Utlendingsdirektoratet eller av Utlendingsnemnda. Lite av hans historie lar seg bevise. Han tilhører ikke en motstandsbevegelse eller noen forfulgt befolkningsgruppe, han er ikke politisk aktiv, og da trenger han vel ingen beskyttelse? Ingen er vel så dumme at de lar samvittigheten styre deres handlinger? Ikke si at du vil risikere familieliv og fremtid i hjemlandet for en edel gjerning? Du kom hit som lykkejeger og for å finne jobb! Dra til hjemlandets ambassade, be om unnskyldning, få et pass, dra hjem og hold kjeft der. 